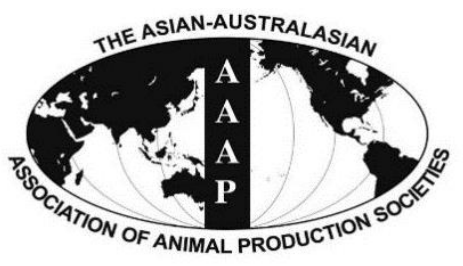

Open Access

Asian Australas. J. Anim. Sci.

Vol. 29, No. 9 : 1322-1330 September 2016

http://dx.doi.org/10.5713/ajas.15.0703

www.ajas.info

pISSN 1011-2367 elSSN 1976-5517

\title{
Standardized Ileal Amino Acid Digestibility of Commonly Used Feed Ingredients in Growing Broilers
}

\author{
Zafar Ullah $^{1,2, *}$, Gulraiz Ahmed ${ }^{3}$, Mehr un Nisa ${ }^{4}$, and Muhammad Sarwar ${ }^{1}$ \\ ${ }^{1}$ Institute of Animal Sciences, University of Agriculture, Faisalabad 38000, Pakistan
}

\begin{abstract}
This experiment was conducted to determine standardized ileal amino acid digestibility (SIAAD) of commonly used feed ingredients in poultry diets in Pakistan. These feed ingredients included corn, rice broken (RB), rice polishings (RP), wheat bran (WB), sunflower meal (SFM), cottonseed meal (CSM), guar meal (GM), soybean meal (SBM) from India and Argentine and fish meal (FM). The SIAAD of each ingredient was determined in triplicate using 21-days-old broilers. Day-old male broiler chicks (Hubbardx Hubbard) were reared on corn-SBM based diet from 1 to 13 days and thereafter birds were fed experimental diets from day 14 to 21 . Each diet was fed to 36 birds kept in six replicate cages, each cage had six birds. In cereals, the SIAAD of corn's amino acid (AA) $(90.1 \%)$ was similar ( $p>0.05)$ to RB $(89.0 \%)$. Isoleucine $(97.8 \%)$ and lysine $(96.9 \%)$ were highly digestible AA in corn and RB, respectively. Among cereal-by products, WB's SIAAD (76.9\%) was same (p>0.05) as RP (71.9\%). Arginine from WB (82.5\%) and RP (83.2\%) was highly digestible. However, threonine in WB (72.7\%) and leucine in RP (69.6\%) were the lowest digestible AAs. In plant protein meals, AAs from Argentine-SBM $(85.1 \%)$ and Indian-SBM $(83.4 \%)$ had higher $(\mathrm{p}<0.5)$ SIAAD than other protein meals. However, SIAAD of SFM (77.1\%) and CSM (71.7\%) was intermediate while GM (60.3\%) exhibited the lowest (p<0.05) SIAAD among all ingredients. Arginine from GM (76.9\%), CSM (85.8\%), SBM-India (89.5\%) and SBM-Argentine (91.5\%) was highly digestible from indispensable AAs. In SFM, methionine (91.4\%) SIAAD was the greatest. The average SIAAD of FM was 77.6\%. Alanine from FM had the highest $(84.0 \%)$ but cysteine $(62.8 \%)$ had the lowest SIAAD. In conclusion, cereals i.e. corn and RB had higher (p<0.05) SIAAD of the cereals by-products. The SIAAD of RP and WB was same $(p>0.05)$. The SBM from plant protein meals had higher ( $<<0.05)$ SIAAD than other studied feed ingredients. However, the GM had the lowest $(\mathrm{p}<0.05)$ SIAAD among protein meals. (Key Words: Broilers, Cereals, Cereal By-products, Digestible Amino Acids)
\end{abstract}

\section{INTRODUCTION}

Amino acids (AA) are critical dietary components regulating the animal's physiological, metabolic and structural functions. To achieve optimum growth performance, the supply of these dietary AAs according to bird's requirement is mandatory. Provision of required dietary AA to birds results in their efficient utilization

\footnotetext{
* Corresponding Author: Zafar Ullah. Tel: +92-333-6851951, E-mail: zu2005@yahoo.com

2 Department of Animal Sciences, University of Sargodha, Sargodha 40100, Pakistan.

${ }^{3}$ Sadiq Feeds (Pvt.) Ltd., Rawalpindi 46300, Pakistan.

${ }^{4}$ Department of Food Science, Nutrition and Home Economics, Government College University, Faisalabad 38000, Pakistan. Submitted Aug. 25, 2015; Revised Nov. 16, 2015; Accepted Jan. 5, 2016
}

because any AA's excess or deficiency adversely affects bird's growth performance.

Interest in determining the AA digestibility has been increased since some scientists (Sibbald, 1987) developed rapid bioassay to estimate AA digestibility. Bioavailability of AAs to birds is key aspect in assessing the protein quality. The AA bioavailability is the portion of AA that is digested, absorbed and utilized by the animal. However, Ravindran et al. (2005) documented that under certain situations, AAs are absorbed in a form not suitable for animal utilization, making no contribution in animal's maintenance and production requirement. Thus, digestible AA (DAA) are more authentic in describing the available AA than total AA. Bioavailability values can be estimated through slope-ratio technique but it underestimates the AA digestibility (Stein et al., 2007) so DAAs assays are more valid approach (Stein 
Table 1. Nutrient composition ${ }^{1}$ of cereals and cereal by-products, used in digestibility assays (as-fed basis)

\begin{tabular}{lcrrr}
\hline \multirow{2}{*}{ Nutrient (\%) } & \multicolumn{3}{c}{ Ingredients } \\
\cline { 2 - 5 } & \multicolumn{1}{c}{ Corn } & Rice broken & Rice polishings & Wheat bran \\
\hline Moisture & $8.67 \pm 0.44$ & $9.87 \pm 0.40$ & $6.84 \pm 0.62$ & $8.20 \pm 1.28$ \\
Crude protein & $8.81 \pm 0.54$ & $10.07 \pm 0.21$ & $12.38 \pm 0.90$ & $13.50 \pm 0.71$ \\
Ether extract & $3.61 \pm 0.07$ & $1.21 \pm 0.05$ & $10.74 \pm 1.44$ & $3.33 \pm 0.47$ \\
Crude fiber & $1.95 \pm 0.12$ & $0.68 \pm 0.02$ & $17.38 \pm 4.06$ & $10.21 \pm 1.63$ \\
Ash & $1.25 \pm 0.17$ & $1.01 \pm 0.14$ & $11.55 \pm 0.63$ & $5.09 \pm 0.49$ \\
Acid insoluble ash & $0.08 \pm 0.06$ & $0.17 \pm 0.04$ & $7.92 \pm 0.72$ & $1.20 \pm 0.43$ \\
\hline
\end{tabular}

${ }^{1}$ Data were average of three samples of each feed ingredient.

et al., 2007). Moreover, some workers claimed that digestibility values determined in mature birds could not be used to formulate growing bird's diet because AA requirements change with bird's age (Adedokun et al., 2008); the ileal digestibility enables AA digestibility assay possible in growing birds and is more reliable tool to represent AA digestibility (Ravindran et al., 1999) than total tract digestibility. Standardized ileal AA digestibility (SIAAD) is widely used technique to present AA digestibility (Adedokun et al., 2008).

Reliable DAA values permitted more efficient broiler production (Lemme et al., 2004). Currently, nutritionists are formulating feeds on DAA basis (Huang et al., 2005). The low dietary protein was maximally utilized by birds for their maintenance and production requirements and this decreases both feed cost and nitrogen excretion into environment, decreasing limiting AA requirements (Dari et al., 2005). Most of the advanced countries have developed ileal-based DAA database of feedstuffs produced in their respective countries (Bryden et al., 2009). But unfortunately, the same database of locally produced ingredients in Pakistan is limited. Thus, the present experiment was conducted with the objective to determine SIAAD of various feed ingredients used in poultry diet in Pakistan.

\section{MATERIALS AND METHODS}

This experiment was conducted at Research and Development Center, Sadiq Feeds (Pvt.) Ltd. Rawalpindi, Pakistan with collaboration Institute of Animal Sciences,
University of Agriculture Faisalabad, Pakistan.

\section{Test ingredients}

Feed ingredients used in this study were two cereals; corn (Zea mays L.) and rice broken (RB) (Oryza sativa L.); two cereal by-products; wheat (Triticum spp.) bran and rice (Oryza sativa L.) polishing; five oil seed meals; sunflower (Helianthus annus L.), cottonseed (Gossypoum spp.), guar (Cyamopsis tetragonolobus L.) and soybean (Glycine max L.) from Argentine and India and one animal protein meal, the fish meal (FM). The 3 samples of each feed ingredient were assayed for SIAAD. These ingredients were analyzed (Tables 1 and 2) for dry matter, crude protein $(\mathrm{N} \times 6.25)$ by LECO nitrogen analyzer (model FP-528, Leco Corporation, St. Joseph, MI, USA), ether extract, crude fiber, ash and acid insoluble ash content (AOAC, 2000).

\section{Experimental diets}

The thirty diets (10 ingredients $\times 3$ samples) were formulated such that all AA were provided from test ingredient in its respective diet. Cereals and cereal byproducts were $91.8 \%$ of diet. The inclusion level of protein meal in diets was adjusted on crude protein $(\mathrm{CP})$ basis so that dietary CP remained about 20\% (Ravindran et al., 2005). Dextrose was used as energy source in these diets. Acid insoluble ash, an external digestibility marker, was added at $2 \%$ to each diet (Ravindran et al., 2005). Calcium and phosphorus supplementation was identical in diets formulated using sunflower meal (SFM), cottonseed meal (CSM), guar meal (GM), soybean meal (SBM)-Argentine

Table 2. Nutrient composition ${ }^{1}$ of protein meals, used in digestibility assays (as-fed basis)

\begin{tabular}{|c|c|c|c|c|c|c|}
\hline \multirow[b]{2}{*}{ Nutrient $(\%)$} & \multicolumn{6}{|c|}{ Ingredients } \\
\hline & Sunflower meal & Guar meal & Cotton seed meal & Fish meal & $\begin{array}{c}\text { Soybean meal } \\
\text { (India) }\end{array}$ & $\begin{array}{c}\text { Soybean meal } \\
\text { (Argentine) }\end{array}$ \\
\hline Moisture & $6.85 \pm 1.75$ & $5.05 \pm 0.33$ & $6.83 \pm 0.26$ & $11.06 \pm 2.41$ & $8.14 \pm 0.52$ & $7.86 \pm 0.27$ \\
\hline Crude protein & $27.07 \pm 1.91$ & $40.46 \pm 0.39$ & $37.85 \pm 4.83$ & $44.92 \pm 2.35$ & $50.70 \pm 0.16$ & $46.38 \pm 0.30$ \\
\hline Ether extract & $0.75 \pm 0.26$ & $5.35 \pm 0.23$ & $1.88 \pm 1.68$ & $17.76 \pm 4.17$ & $0.53 \pm 0.15$ & $1.18 \pm 0.15$ \\
\hline Crude fiber & $24.81 \pm 3.55$ & $13.06 \pm 0.46$ & $13.87 \pm 3.65$ & - & $5.08 \pm 1.02$ & $3.66 \pm 0.40$ \\
\hline Ash & $6.51 \pm 0.74$ & $5.75 \pm 0.29$ & $6.71 \pm 0.46$ & $23.58 \pm 3.95$ & $7.39 \pm 0.14$ & $6.57 \pm 0.15$ \\
\hline Acid insoluble ash & $1.93 \pm 0.86$ & $1.26 \pm 0.32$ & $0.48 \pm 0.12$ & $10.97 \pm 1.74$ & $1.15 \pm 0.20$ & $1.02 \pm 0.08$ \\
\hline
\end{tabular}

${ }^{1}$ Data were average of three samples of each feed ingredient. 
Table 3. Ingredient composition of experimental diets used in digestibility assays-selected examples (as-fed basis)

\begin{tabular}{|c|c|c|c|c|c|c|c|}
\hline \multirow[b]{2}{*}{ Ingredients (\%) } & \multicolumn{7}{|c|}{ Ingredients } \\
\hline & $\begin{array}{l}\text { Cereal and cereal } \\
\text { by-products }\end{array}$ & $\begin{array}{c}\text { Cotton seed } \\
\text { meal }\end{array}$ & $\begin{array}{c}\text { Sunflower } \\
\text { meal }\end{array}$ & Guar meal & Fish meal & $\begin{array}{c}\text { Soybean meal } \\
\text { (India) }\end{array}$ & $\begin{array}{c}\text { Soybean meal } \\
\text { (Argentine) }\end{array}$ \\
\hline Test ingredient $^{1}$ & 91.8 & 52.84 & 72.53 & 47.53 & 44.52 & 39.44 & 43.29 \\
\hline Dextrose & - & 35.06 & 15.37 & 40.37 & 47.28 & 48.46 & 44.61 \\
\hline Sunflower oil & 2.0 & 6.0 & 6.0 & 6.0 & 2.0 & 6.0 & 6.0 \\
\hline Arbocel $^{2}$ (cellulose) & - & - & - & - & 3.0 & - & - \\
\hline Celite & 2.0 & 2.0 & 2.0 & 2.0 & 2.0 & 2.0 & 2.0 \\
\hline Dicalcium phosphate & 1.7 & 1.9 & 1.9 & 1.9 & - & 1.9 & 1.9 \\
\hline Limestone & 1.3 & 1.0 & 1.0 & 1.0 & - & 1.0 & 1.0 \\
\hline Vit/min premix ${ }^{3}$ & 0.7 & 0.7 & 0.7 & 0.7 & 0.7 & 0.7 & 0.7 \\
\hline Choline chloride & 0.3 & 0.3 & 0.3 & 0.3 & 0.3 & 0.3 & 0.3 \\
\hline Salt & 0.2 & 0.2 & 0.2 & 0.2 & 0.2 & 0.2 & 0.2 \\
\hline
\end{tabular}

${ }^{1}$ Test ingredient served as sole source of amino acid. Except cereals and cereal by-products, test ingredients were included to supply approximately $20 \%$ dietary crude protein.

${ }^{2}$ Arbocel, Insoluble raw fiber concentrate, Holzmuhle, Rosenberg, Germany.

${ }^{3}$ Provided per kg of diet: retinyl acetate, 4,400 IU; cholecalciferol, $118 \mu \mathrm{g}$; DL- $\alpha$-tocopheryl acetate, $12 \mathrm{IU}$; menadione sodium bisulphite, $2.40 \mathrm{mg}$; thiamine, $2.5 \mathrm{mg}$; riboflavin, $4.8 \mathrm{mg}$; niacin, $30 \mathrm{mg}$; D-pentothenic acid, $10 \mathrm{mg}$; pyridoxine, $5 \mathrm{mg}$; biotin, $130 \mu \mathrm{g}$; folic acid, $2.5 \mathrm{mg}$; cyanocobalamin, $19 \mu \mathrm{g}$; manganese, $85 \mathrm{mg}\left(\mathrm{MnSO}_{4} \cdot \mathrm{H}_{2} \mathrm{O}\right)$; iron, $80 \mathrm{mg}\left(\mathrm{FeSO}_{4} \cdot \mathrm{H}_{2} \mathrm{O}\right)$; zinc, $75 \mathrm{mg}(\mathrm{ZnO})$; copper, $6 \mathrm{mg}\left(\mathrm{CuSO}_{4} \cdot 5 \mathrm{H}_{2} \mathrm{O}\right)$; iodine, 1 mg (ethylene diamine dihydroiodide); selenium, $130 \mu \mathrm{g}\left(\mathrm{Na}_{2} \mathrm{SeO}_{3}\right)$.

and SMB-India. However, calcium and phosphorus supplementation was not added in 3 diets containing FM but these diets contained 3\% Arbocel as fiber source (Ravindran et al., 2005). Vitamin and mineral supplementation was similar across all diets (Table 3). A nitrogen free diet (NFD) was formulated (Table 4) to determine endogenous AA losses (EAA) (Table 7) to calculate SIAAD (Adedokun et al., 2007).

Table 4. Ingredient composition of nitrogen free diet (as-fed basis)

\begin{tabular}{lc}
\hline Ingredients & Percentage \\
\hline Corn starch & 16.9 \\
Dextrose & 64.0 \\
Sunflower oil & 5.0 \\
Arbocel (cellulose) $^{1}$ & 5.0 \\
Celite & 2.0 \\
Dicalcium phosphate & 1.9 \\
Limestone & 1.3 \\
Vit/min premix & \\
Choline chloride & 0.7 \\
Salt & 0.3 \\
Sodium bicarbonate & 0.2 \\
Potassium chloride & 1.5 \\
\hline
\end{tabular}

${ }^{1}$ Arbocel, Insoluble raw fiber concentrate, Holzmuhle, Rosenberg, Germany.

${ }^{2}$ Provided per kg of diet: retinyl acetate, 4,400 IU; cholecalciferol, $118 \mu \mathrm{g}$; DL- $\alpha$-tocopheryl acetate, $12 \mathrm{IU}$; menadione sodium bisulphite, $2.40 \mathrm{mg}$; thiamine, $2.5 \mathrm{mg}$; riboflavin, $4.8 \mathrm{mg}$; niacin, $30 \mathrm{mg}$; D-pentothenic acid, $10 \mathrm{mg}$; pyridoxine, $5 \mathrm{mg}$; biotin, $130 \mu \mathrm{g}$; folic acid, $2.5 \mathrm{mg}$; cyanocobalamin, $19 \mu \mathrm{g}$; manganese, $85 \mathrm{mg}\left(\mathrm{MnSO}_{4} \mathrm{H}_{2} \mathrm{O}\right)$; iron, $80 \mathrm{mg}$ $\left(\mathrm{FeSO}_{4} \cdot \mathrm{H}_{2} \mathrm{O}\right)$; zinc, $75 \mathrm{mg}(\mathrm{ZnO})$; copper, $6 \mathrm{mg}\left(\mathrm{CuSO}_{4} \cdot 5 \mathrm{H}_{2} \mathrm{O}\right)$; iodine, 1 $\mathrm{mg}$ (ethylene diamine dihydroiodide); selenium, $130 \mu \mathrm{g}\left(\mathrm{Na}_{2} \mathrm{SeO}_{3}\right)$.

\section{Bird's management}

A total of 1,116 day-old male broiler chicks (Hubbardx Hubbard) were arranged from commercial hatchery (SB Hatchery, Rawalpindi, Pakistan) and kept in cages. All chicks were reared under identical managemental conditions. Room temperature was maintained at $32^{\circ} \mathrm{C} \pm 1^{\circ} \mathrm{C}$ during 1 st week and gradually decreased to $24^{\circ} \mathrm{C}$ by the end of 3 rd week. Birds received continuous fluorescent light throughout the experimental period. Chicks were vaccinated against Newcastle Disease (ND), Infectious Bronchitis (IB) and Infectious Bursal Disease (IBD). Supply of fresh and clean water was made available round the clock. Chicks were fed ad-libitum corn-SBM starter diet in crumble form to fulfill their nutritional requirements (NRC, 1994) from day 1 to 13 . On day 14, all the chicks were fasted overnight, individually weighed and randomly distributed to 186 replicate cages ( 6 birds in each cage) in similar cumulative body weight manner among all cages. The variation in mean body weight among replicates was $\pm 10 \mathrm{~g}$. Experimental diets were offered to birds from day 14 to 21 of age. Each experimental diet was offered ad-libitum to 36 birds kept in 6 replicates; each replicate had 6 birds. So, 3 diets based on 3 samples of same feed ingredient were fed to birds of 18 replicate cages. The NFD diet was offered $a d$ libitum to 36 birds placed in 6 replicate cages.

\section{Ileal digesta collection}

On day 21, all birds were euthanized by intravenous injection, Ketamax (Ketamine hydrochloride). Contents of ileum from vitelline diverticulum (formally named as Meckel's diverticulum) to $40 \mathrm{~mm}$ proximal to ileo-caecal junction (Bandegan et al., 2009) were collected in plastic zip bags by gently flushing through long tip syringe 
containing distilled water and air pressure. The ileal digesta of all birds in a replicate was pooled, immediately stored at $-20^{\circ} \mathrm{C}$ and subsequently freeze-dried (Kong and Adeola, 2014). Dried ileal digesta then ground in coffee grinder (MC3001 coffee grinder; Moulinex Ltd. Weston, ON, Canada) to pass through $0.5 \mathrm{~mm}$ sieve and stored in plastic tubes at $-4^{\circ} \mathrm{C}$ for further analyses (Bandegan et al., 2009).

\section{Chemical analyses}

Raw ingredients, test diets and ileal digesta samples were analyzed for dry matter (DM: AOAC, 2000) and CP $(\mathrm{N} \times 6.25)$ by LECO nitrogen analyzer (model FP-528, Leco Corporation, USA). Acid insoluble ash of both diets and ileal digesta samples were determined (AOAC, 2000). The AA profile of test ingredients (Tables 5 and 6) and ileal digesta was determined by the procedure used by Palliyeguru et al. (2010) using AA analyzer (Biochrom 30 plus, Biochrom Ltd. Cambridge, UK). Samples were oxidized with hydrogen peroxide-formic acid-phenol solution and sodium disulfite was used to decompose excess oxidation reagent. After oxidation, samples were hydrolyzed using $6 \mathrm{M} \mathrm{HCl}$ for 24 hours. The $\mathrm{pH}$ of hydrolysate was adjusted at 2.20 , centrifuged, filtered and AA profile was determined.

\section{Calculations}

The EAA concentration was calculated as milligrams of AA flow per kg DM intake as described by Moughan et al. (1992).

$$
\begin{aligned}
& \text { leal AA flow, mg/kg DMI } \\
& =[\text { AA in ileal digesta, } \mathrm{mg} / \mathrm{kg} \\
& \left.\times\left(\frac{\text { Diet marker, } \mathrm{mg} / \mathrm{kg}}{\text { Ileal marker, } \mathrm{mg} / \mathrm{kg}}\right)\right]
\end{aligned}
$$

Apparent ileal AA digestibility (AIAAD), \%

$$
\begin{aligned}
& =\left[1-\left(\frac{\text { Marker in diet }}{\text { Marker in ileal digesta }}\right)\right. \\
& \left.\times\left(\frac{\text { AA in ileal digesta }}{\text { AA in diet }}\right)\right] \times 100
\end{aligned}
$$

The endogenous ileal AA losses (mg/kg of DM intake) were used (Table 7) to calculate SIAAD by using following equation.

$$
\begin{aligned}
& \text { Standardized ileal AA digestibility (SIAAD), \% } \\
& =\text { AIAAD, } \% \\
& +\left[\left(\frac{\text { Ileal AA flow, } \mathrm{g} / \mathrm{kg} \text { of DMI }}{\text { AA in raw material, } \mathrm{g} / \mathrm{kg} \text { of DMI }}\right)\right. \\
& \times 100]
\end{aligned}
$$

\section{Statistical analyses}

The mean and standard deviation of ingredient's nutrient composition, ingredient's AA profile and SIAAD of test ingredients were calculated to provide information on variability. The average SIAAD values between cereal and cereal by products as well as protein meals were analyzed using Analysis of variance techniques using SAS (2009). Means were compared by Tukey's test.

\section{RESULTS AND DISCUSSION}

\section{Total amino acid concentration}

Cereals and cereal by-products: The average AA concentration of three samples in corn, $\mathrm{RB}$, rice polishings (RP), and wheat bran (WB) ranged from $0.19 \%$ to $1.42 \%$, $0.20 \%$ to $1.59 \%, 0.25 \%$ to $1.67 \%$, and $0.23 \%$ to $2.81 \%$, respectively. In all cereals and cereal by-products, glutamic acid concentration was highest. Its value in corn, RB, RP, and WB was $1.42 \%, 1.59 \%, 1.67 \%$, and $2.81 \%$, respectively. Methionine was the lowermost in corn $(0.19 \%)$, RP $(0.25 \%)$ and WB $(0.23 \%)$; however, in RB, cysteine concentration $(0.20 \%)$ was the lowest (Table 5). The AA concentration of feed ingredients in this study was commensurate with other literature (Heartland Lysine, 1996; Evonik, 2010). The minor variation in WB's AA concentration in present study compared to those reported by Evonik (2010) might be because of difference in $\mathrm{CP}$ content. Generally, AA concentration increases with increasing protein level (Ravindran et al., 2005). Varying plant breeding program,

Table 5. Total amino acid composition ${ }^{1}$ of cereals and cereal byproducts, used in digestibility assays (as-fed basis)

\begin{tabular}{lcccc}
\hline & \multicolumn{4}{c}{ Ingredients } \\
\cline { 2 - 5 } Amino acid (\%) & Corn & $\begin{array}{c}\text { Rice } \\
\text { broken }\end{array}$ & $\begin{array}{c}\text { Rice } \\
\text { polishings }\end{array}$ & Wheat bran \\
\hline Dry matter & $91.33 \pm 0.44$ & $90.13 \pm 0.40$ & $93.16 \pm 0.62$ & $91.80 \pm 1.28$ \\
Indispensable amino acid & & & \\
Arginine & $0.42 \pm 0.06$ & $0.71 \pm 0.05$ & $0.88 \pm 0.04$ & $1.00 \pm 0.08$ \\
Histidine & $0.27 \pm 0.05$ & $0.21 \pm 0.01$ & $0.33 \pm 0.03$ & $0.42 \pm 0.02$ \\
Isoleucine & $0.27 \pm 0.04$ & $0.37 \pm 0.02$ & $0.41 \pm 0.04$ & $0.45 \pm 0.08$ \\
Leucine & $0.83 \pm 0.09$ & $0.74 \pm 0.05$ & $0.81 \pm 0.08$ & $0.88 \pm 0.09$ \\
Lysine & $0.28 \pm 0.05$ & $0.33 \pm 0.02$ & $0.54 \pm 0.03$ & $0.61 \pm 0.07$ \\
Methionine & $0.19 \pm 0.03$ & $0.25 \pm 0.02$ & $0.25 \pm 0.04$ & $0.23 \pm 0.04$ \\
Phenylalanine & $0.39 \pm 0.08$ & $0.48 \pm 0.03$ & $0.56 \pm 0.08$ & $0.58 \pm 0.12$ \\
Threonine & $0.28 \pm 0.04$ & $0.32 \pm 0.02$ & $0.45 \pm 0.05$ & $0.50 \pm 0.04$ \\
Valine & $0.41 \pm 0.07$ & $0.53 \pm 0.03$ & $0.65 \pm 0.08$ & $0.69 \pm 0.13$ \\
Dispensable amino acid & & & \\
Alanine & $0.53 \pm 0.06$ & $0.52 \pm 0.03$ & $0.71 \pm 0.06$ & $0.72 \pm 0.06$ \\
Aspartic acid & $0.51 \pm 0.08$ & $0.80 \pm 0.04$ & $1.02 \pm 0.04$ & $1.06 \pm 0.05$ \\
Cysteine & $0.21 \pm 0.03$ & $0.20 \pm 0.02$ & $0.26 \pm 0.02$ & $0.30 \pm 0.03$ \\
Glycine & $0.33 \pm 0.05$ & $0.40 \pm 0.02$ & $0.65 \pm 0.06$ & $0.79 \pm 0.04$ \\
Glutamic acid & $1.42 \pm 0.27$ & $1.59 \pm 0.10$ & $1.67 \pm 0.18$ & $2.81 \pm 0.29$ \\
Serine & $0.35 \pm 0.03$ & $0.44 \pm 0.03$ & $0.51 \pm 0.02$ & $0.61 \pm 0.03$ \\
\hline Data were average of three samples of each feed ingredient.
\end{tabular}


agronomic practices, cultivation season and soil conditions are reported to influence chemical composition and AA contents of feed ingredients (Ravindran et al., 2014).

Protein meals: The AA contents of SFM, GM, CSM, FM, SBM-India and SBM-Argentine ranged from $0.49 \%$ to $5.64 \%, 0.40 \%$ to $7.01 \%, 0.64 \%$ to $8.60 \%, 0.28 \%$ to $4.39 \%$, $0.64 \%$ to $9.24 \%$, and $0.57 \%$ to $8.20 \%$ (Table 6), respectively. Glutamic acid concentration was the highest in all ingredients. Methionine was the lowest in GM (0.40\%), CSM $(0.64 \%)$ and SBM from both regions. However, in SFM $(0.49 \%)$ and FM $(0.28 \%)$, cysteine concentration was the lowest. Similar results were reported by other workers (Heartland Lysine, 1996; Ravindran et al., 2005).

\section{Standardized ileal amino acid digestibility}

Cereals and cereal by-products: The mean SIAAD of corn, RB, RP, and WB ranged from $79.4 \%$ to $97.8 \%, 82.1 \%$ to $96.9 \%$, $64.9 \%$ to $83.2 \%$, and $71.1 \%$ to $82.8 \%$, respectively (Table 8). The overall mean AA digestibility of corn $(90.1 \%)$ was same $(\mathrm{p}>0.05)$ compared to RB $(89.0 \%)$. Likewise, the WB exhibited equal ( $p>0.05$ ) SIAAD (76.9\%) compared to RP (71.9\%). The numerically lower RP's SIAAD than WB, supported the findings of Warren and Farrell (1991). Ravindran et al. (2005) reported higher apparent digestibility of wheat middlings than RP. Corn's SIAAD (90.1\%) was concordant with those reported by Sauvant et al. (2004), Rostagno et al. (2005) and Evonik (2010). However, it was higher than those reported by Ravindran et al. (2005). The SIAAD of WB (76.9\%) was also concordant with the values reported by Evonik (2010),
Table 7. Concentration of endogenous amino acid losses used to standardize the amino acid digestibility

\begin{tabular}{lc}
\hline Amino acid & $\begin{array}{c}\text { Endogenous amino acid concentration } \\
(\mathrm{mg} / \mathrm{kg} \mathrm{DMI})\end{array}$ \\
\hline Indispensable amino acid & 179 \\
Arginine & 189 \\
Histidine & 349 \\
Isoleucine & 341 \\
Leucine & 225 \\
Lysine & 49 \\
Methionine & 202 \\
Phenylalanine & 412 \\
Threonine & 396 \\
Valine & \\
Dispensable amino acid & 108 \\
Alanine & 168 \\
Aspartic acid & 141 \\
Cysteine & 120 \\
Glycine & 237 \\
Glutamic acid & 136 \\
Serine &
\end{tabular}

DMI, dry matter intake.

Rostagno et al. (2005) and Sauvant et al. (2004). The SIAAD of RB $(89.0 \%)$ of our study supported the findings reported by Sauvant et al. (2004). However, some variations were also reported by Evonik (2010). The SIAAD of RP $(71.9 \%)$ in present study was supported by the findings of Evonik (2010). However, contrasting results were reported by Sauvant et al. (2004), Rostagno et al. (2005) and

Table 6. Total amino acid composition ${ }^{1}$ of protein meals, used in digestibility assays (as-fed basis)

\begin{tabular}{|c|c|c|c|c|c|c|}
\hline \multirow[b]{2}{*}{ Amino acid (\%) } & \multicolumn{6}{|c|}{ Ingredients } \\
\hline & Sunflower meal & Guar meal & Cotton seed meal & Fish meal & $\begin{array}{c}\text { Soybean meal } \\
\text { (India) }\end{array}$ & $\begin{array}{c}\text { Soybean meal } \\
\text { (Argentine) }\end{array}$ \\
\hline Dry matter & $93.15 \pm 1.75$ & $94.95 \pm 0.33$ & $93.17 \pm 0.26$ & $88.94 \pm 2.41$ & $91.86 \pm 0.52$ & $92.14 \pm 0.27$ \\
\hline \multicolumn{7}{|c|}{ Indispensable amino acid } \\
\hline Arginine & $2.29 \pm 0.38$ & $4.50 \pm 0.20$ & $4.38 \pm 0.39$ & $1.57 \pm 0.13$ & $3.62 \pm 0.09$ & $3.17 \pm 0.16$ \\
\hline Histidine & $0.73 \pm 0.14$ & $0.97 \pm 0.04$ & $1.20 \pm 0.05$ & $0.72 \pm 0.08$ & $1.35 \pm 0.04$ & $1.23 \pm 0.03$ \\
\hline Isoleucine & $1.19 \pm 0.23$ & $1.10 \pm 0.02$ & $1.39 \pm 0.06$ & $1.45 \pm 0.30$ & $2.31 \pm 0.08$ & $1.86 \pm 0.25$ \\
\hline Leucine & $1.80 \pm 0.32$ & $2.11 \pm 0.02$ & $2.51 \pm 0.05$ & $2.42 \pm 0.38$ & $3.81 \pm 0.08$ & $3.31 \pm 0.17$ \\
\hline Lysine & $0.99 \pm 0.18$ & $1.51 \pm 0.12$ & $1.56 \pm 0.17$ & $1.99 \pm 0.32$ & $3.01 \pm 0.06$ & $2.69 \pm 0.14$ \\
\hline Methionine & $0.66 \pm 0.17$ & $0.40 \pm 0.02$ & $0.64 \pm 0.01$ & $0.76 \pm 0.12$ & $0.64 \pm 0.06$ & $0.57 \pm 0.03$ \\
\hline Phenylalanine & $1.32 \pm 0.25$ & $1.45 \pm 0.09$ & $2.37 \pm 0.02$ & $1.38 \pm 0.16$ & $2.58 \pm 0.12$ & $2.19 \pm 0.19$ \\
\hline Threonine & $1.05 \pm 0.18$ & $1.14 \pm 0.06$ & $1.41 \pm 0.06$ & $1.22 \pm 0.15$ & $1.91 \pm 0.05$ & $1.78 \pm 0.04$ \\
\hline Valine & $1.43 \pm 0.27$ & $1.29 \pm 0.02$ & $1.77 \pm 0.07$ & $1.78 \pm 0.32$ & $2.39 \pm 0.11$ & $1.90 \pm 0.30$ \\
\hline \multicolumn{7}{|c|}{ Dispensable amino acid } \\
\hline Alanine & $1.21 \pm 0.18$ & $1.52 \pm 0.03$ & $1.80 \pm 0.03$ & $2.43 \pm 0.30$ & $2.12 \pm 0.02$ & $1.97 \pm 0.03$ \\
\hline Aspartic acid & $2.52 \pm 0.35$ & $3.66 \pm 0.04$ & $3.95 \pm 0.12$ & $2.85 \pm 0.31$ & $5.60 \pm 0.08$ & $5.11 \pm 0.04$ \\
\hline Cysteine & $0.49 \pm 0.08$ & $0.44 \pm 0.04$ & $0.69 \pm 0.02$ & $0.28 \pm 0.07$ & $0.71 \pm 0.02$ & $0.63 \pm 0.07$ \\
\hline Glycine & $1.70 \pm 0.28$ & $2.00 \pm 0.01$ & $1.87 \pm 0.02$ & $2.60 \pm 0.23$ & $2.80 \pm 0.02$ & $1.91 \pm 0.03$ \\
\hline Glutamic acid & $5.64 \pm 1.26$ & $7.01 \pm 0.16$ & $8.60 \pm 0.12$ & $4.39 \pm 0.40$ & $9.24 \pm 0.54$ & $8.20 \pm 0.06$ \\
\hline Serine & $1.18 \pm 0.15$ & $1.63 \pm 0.12$ & $1.82 \pm 0.15$ & $1.15 \pm 0.09$ & $2.46 \pm 0.10$ & $2.32 \pm 0.05$ \\
\hline
\end{tabular}

${ }^{1}$ Data were average of three samples of each feed ingredient. 
Ravindran et al. (2005). Reason of this varying AA digestibility might be difference in age of birds and apparent digestibility values without correcting with EAA losses. The apparent digestibility is generally low due to higher EAA proportion in terminal ileum. The AA intake reduced in birds fed diets containing low protein/AA content (Kim et al., 2012b). The decreased AA intake resulted in increased EAA. Moter and Stein (2004) also reported wider variance in apparent and standardized digestibility for low protein ingredients. The method used to estimate EAA losses also influenced SIAAD values (Bryden et al., 2009). Adedokun et al. (2008) reported varying corn SIAAD when EAA were determined by feeding either NFD or $10 \%$ casein diet. In literature, several terminologies and methods have been used to present AA digestibility results (Ravindran et al., 2005; Bryden et al., 2009; Kim et al., 2012a,b). These terms included apparent or true digestibilities using ileal content (intact or cecectomized) or excreta (Ravindran et al., 1999) of varying age roosters, cockerels and broilers (Huang et al., 2005). Therefore, direct comparison of SIAAD values, determined in this study using 21-days old broilers, with reported literature seems really valid.

Some endogenous and exogenous factors have been reported to influence digestibility. The endogenous factors included the specie, strain, age (Kim and Corzo, 2012) and sex (Huang et al., 2005) while exogenous aspects were the presence of antinutritional substances, dietary AA balance and stress level on animals. These factors affect physical, chemical and physiological state of digestive environment (Huang et al., 2005) which may influence AA digestibility. The ingredient's natural variability and their processing also affect AA digestibility (Bell, 1993; Adedokun et al., 2007). More variation in RP's SIAAD in this study may be because of varying both processing techniques and chemical composition of samples. Not only the ingredient's chemical composition influences its digestibility but linkages of protein to other nutrients such as carbohydrates, fats and proteins are also important in this regard (Bryden et al., 2009). The SIAAD of all cereals and cereal by-products differed from each other. The reason may be that each ingredient was a mixture of various proteins and each of them was digested at different rate.

Among cereal and cereal by-product; Isoleucine, lysine, arginine and glutamic acid were highly digestible in corn (97.8\%), RB (96.9\%), RP (83.2\%), and WB (82.8\%), respectively. In indispensable AAs, threonine was the lowest digestible in corn (86.6\%) and WB (72.7\%), methionine in RB $(82.1 \%)$ and leucine in RP $(69.6 \%)$. From dispensable AAs, glycine had the lowest digestibility in corn $(79.4 \%)$, RP $(64.9 \%)$ and WB $(71.1 \%)$. The cysteine (84.0\%) from RB had also the lowest digestibility. The highest glutamic acid digestibility among dispensable AAs (Table 8) supported the findings of other workers (Bryden et al., 2009).

Protein meals: The SIAAD of SBM-Argentine, SBMIndia, SFM, CSM, and GM ranged from $77.2 \%$ to $91.5 \%$, $77.1 \%$ to $89.5 \%, 60.0 \%$ to $91.4 \%, 56.8 \%$ to $85.8 \%$, and

Table 8. Standardized ileal amino acid digestibility percentage of cereals and cereal by-products in broiler chicks ${ }^{1}$

\begin{tabular}{|c|c|c|c|c|c|}
\hline \multirow{2}{*}{ Amino acid (\%) } & \multicolumn{4}{|c|}{ Ingredients } & \multirow{2}{*}{ p-value } \\
\hline & Corn & Rice broken & Rice polishings & Wheat bran & \\
\hline \multicolumn{6}{|c|}{ Indispensable amino acid } \\
\hline Arginine & $93.3^{\mathrm{a}} \pm 1.27$ & $94.4^{\mathrm{a}} \pm 1.87$ & $83.2^{\mathrm{b}} \pm 3.81$ & $82.5^{\mathrm{b}} \pm 1.39$ & $* * *$ \\
\hline Histidine & $91.5^{\mathrm{a}} \pm 2.29$ & $92.6^{\mathrm{a}} \pm 2.76$ & $75.2^{\mathrm{b}} \pm 1.92$ & $77.5^{\mathrm{b}} \pm 0.86$ & $* * *$ \\
\hline Isoleucine & $97.8^{\mathrm{a}} \pm 1.15$ & $93.2^{\mathrm{a}} \pm 3.68$ & $75.0^{\mathrm{b}} \pm 7.12$ & $81.0^{\mathrm{b}} \pm 0.87$ & $* * *$ \\
\hline Leucine & $94.7^{\mathrm{a}} \pm 1.31$ & $89.5^{\mathrm{a}} \pm 3.28$ & $69.6^{\mathrm{b}} \pm 6.16$ & $78.6^{\mathrm{b}} \pm 1.87$ & $* * *$ \\
\hline Lysine & $91.0^{\mathrm{a}} \pm 2.73$ & $96.9^{\mathrm{a}} \pm 2.03$ & $80.6^{\mathrm{b}} \pm 4.01$ & $78.6^{\mathrm{b}} \pm 2.91$ & $* * *$ \\
\hline Methionine & $94.9^{\mathrm{a}} \pm 0.99$ & $82.1^{\mathrm{ab}} \pm 4.62$ & $72.1^{\mathrm{b}} \pm 8.82$ & $81.7^{\mathrm{b}} \pm 1.66$ & $* *$ \\
\hline Phenylalanine & $94.2^{\mathrm{a}} \pm 0.47$ & $88.6^{\mathrm{a}} \pm 3.28$ & $70.1^{\mathrm{b}} \pm 7.13$ & $72.8^{\mathrm{b}} \pm 3.11$ & $* * *$ \\
\hline Threonine & $86.6^{a} \pm 3.29$ & $91.1^{\mathrm{a}} \pm 4.87$ & $70.7^{b} \pm 5.13$ & $72.7^{\mathrm{b}} \pm 1.59$ & $* * *$ \\
\hline Valine & $92.6^{\mathrm{a}} \pm 0.76$ & $91.6^{\mathrm{a}} \pm 3.23$ & $71.4^{\mathrm{b}} \pm 5.60$ & $76.1^{\mathrm{b}} \pm 1.57$ & $* * *$ \\
\hline \multicolumn{6}{|c|}{ Dispensable amino acid } \\
\hline Alanine & $90.1^{\mathrm{a}} \pm 1.70$ & $87.0^{\mathrm{a}} \pm 3.13$ & $70.6^{b} \pm 3.36$ & $73.5^{\mathrm{b}} \pm 2.31$ & $* * *$ \\
\hline Aspartic acid & $83.4^{\mathrm{a}} \pm 2.02$ & $88.4^{\mathrm{a}} \pm 2.55$ & $70.6^{\mathrm{b}} \pm 4.84$ & $74.1^{\mathrm{b}} \pm 1.29$ & $* * *$ \\
\hline Cysteine & $88.6^{\mathrm{a}} \pm 3.05$ & $84.0^{\mathrm{ab}} \pm 4.90$ & $66.2^{c} \pm 5.73$ & $76.3^{\mathrm{bc}} \pm 0.78$ & $* * *$ \\
\hline Glycine & $79.4^{\mathrm{a}} \pm 1.54$ & $86.5^{\mathrm{a}} \pm 2.96$ & $64.9^{\mathrm{b}} \pm 4.95$ & $71.1^{\mathrm{b}} \pm 0.96$ & $* * *$ \\
\hline Glutamic acid & $91.3^{a} \pm 1.91$ & $85.0^{\mathrm{a}} \pm 3.78$ & $71.7^{b} \pm 4.86$ & $82.8^{a} \pm 1.49$ & $* * *$ \\
\hline Serine & $82.3^{\mathrm{ab}} \pm 3.43$ & $84.7^{\mathrm{a}} \pm 3.21$ & $66.8^{c} \pm 6.55$ & $73.8^{\mathrm{bc}} \pm 1.48$ & $* *$ \\
\hline Average & $90.1^{\mathrm{a}} \pm 5.18$ & $89.0^{\mathrm{a}} \pm 4.23$ & $71.9^{\mathrm{b}} \pm 4.97$ & $76.9^{\mathrm{b}} \pm 3.87$ & $* * *$ \\
\hline
\end{tabular}

${ }^{1}$ Data were average of 3 samples of each feed ingredient; diet based on each sample was fed to six replicates each containing six birds.

a,b,c,d Values sharing different superscripts within rows are statistically significant $(\mathrm{p}<0.05)$.

$* \mathrm{p}<0.05 ; * * \mathrm{p}<0.01 ; * * * \mathrm{p}<0.001$. 
Table 9. Standardized ileal amino acid digestibility percentage of protein meals in broiler chicks ${ }^{1}$

\begin{tabular}{|c|c|c|c|c|c|c|c|}
\hline \multirow[b]{2}{*}{ Amino acid (\%) } & \multicolumn{6}{|c|}{ Ingredients } & \multirow[b]{2}{*}{ p-value } \\
\hline & Sunflower meal & Guar meal & Cotton seed meal & Fish meal & $\begin{array}{l}\text { Soybean meal } \\
\text { (India) }\end{array}$ & $\begin{array}{c}\text { Soybean meal } \\
\text { (Argentine) }\end{array}$ & \\
\hline \multicolumn{8}{|c|}{ Indispensable amino acid } \\
\hline Arginine & $90.9^{\mathrm{a}} \pm 1.08$ & $76.9^{b} \pm 9.15$ & $85.8^{\mathrm{ab}} \pm 1.63$ & $82.6^{\mathrm{ab}} \pm 1.55$ & $89.5^{\mathrm{a}} \pm 1.16$ & $91.5^{\mathrm{a}} \pm 2.65$ & $* *$ \\
\hline Histidine & $77.0^{\mathrm{b}} \pm 3.20$ & $65.1^{\mathrm{c}} \pm 3.89$ & $75.0^{\mathrm{b}} \pm 2.72$ & $75.5^{\mathrm{b}} \pm 3.90$ & $87.1^{\mathrm{a}} \pm 1.64$ & $87.9^{\mathrm{a}} \pm 2.96$ & $* * *$ \\
\hline Isoleucine & $83.9^{\mathrm{ab}} \pm 1.60$ & $58.5^{\mathrm{d}} \pm 3.92$ & $70.5^{c} \pm 2.78$ & $78.5^{\mathrm{bc}} \pm 5.84$ & $86.1^{\mathrm{ab}} \pm 2.20$ & $87.8^{\mathrm{a}} \pm 2.17$ & $* * *$ \\
\hline Leucine & $82.1^{\mathrm{a}} \pm 1.51$ & $60.3^{c} \pm 2.85$ & $73.9^{\mathrm{b}} \pm 1.97$ & $82.6^{\mathrm{a}} \pm 1.90$ & $84.6^{a} \pm 2.18$ & $87.1^{\mathrm{a}} \pm 2.45$ & $* * *$ \\
\hline Lysine & $78.3^{\mathrm{bc}} \pm 2.93$ & $57.3^{\mathrm{d}} \pm 3.74$ & $56.8^{\mathrm{d}} \pm 4.31$ & $72.7^{c} \pm 4.34$ & $86.7^{\mathrm{ab}} \pm 2.08$ & $89.6^{\mathrm{a}} \pm 3.55$ & $* * *$ \\
\hline Methionine & $91.4^{\mathrm{a}} \pm 0.62$ & $63.8^{\mathrm{c}} \pm 4.14$ & $75.0^{\mathrm{b}} \pm 2.02$ & $79.1^{\mathrm{b}} \pm 1.18$ & $87.9^{\mathrm{a}} \pm 3.37$ & $89.8^{\mathrm{a}} \pm 2.13$ & $* * *$ \\
\hline Phenylalanine & $78.9^{\mathrm{ab}} \pm 7.39$ & $60.4^{\mathrm{b}} \pm 4.55$ & $71.2^{\mathrm{ab}} \pm 14.15$ & $81.1^{\mathrm{a}} \pm 1.32$ & $84.7^{\mathrm{a}} \pm 0.31$ & $85.4^{\mathrm{a}} \pm 2.78$ & $* *$ \\
\hline Threonine & $73.1^{\mathrm{bc}} \pm 3.09$ & $52.6^{\mathrm{d}} \pm 4.23$ & $67.7^{\mathrm{c}} \pm 1.90$ & $77.3^{\mathrm{ab}} \pm 3.23$ & $82.0^{\mathrm{a}} \pm 1.91$ & $83.7^{\mathrm{a}} \pm 3.66$ & $* * *$ \\
\hline Valine & $78.7^{\mathrm{bc}} \pm 1.96$ & $53.6^{\mathrm{d}} \pm 5.73$ & $68.9^{c} \pm 2.50$ & $77.1^{\mathrm{ab}} \pm 4.34$ & $84.5^{\mathrm{a}} \pm 2.45$ & $86.5^{\mathrm{a}} \pm 2.53$ & $* * *$ \\
\hline \multicolumn{8}{|c|}{ Dispensable amino acid } \\
\hline Alanine & $79.5^{\mathrm{ab}} \pm 2.68$ & $51.4^{\mathrm{c}} \pm 6.61$ & $72.3^{b} \pm 1.50$ & $84.0^{\mathrm{a}} \pm 2.67$ & $83.2^{\mathrm{a}} \pm 2.35$ & $84.8^{\mathrm{a}} \pm 0.94$ & $* * *$ \\
\hline Aspartic acid & $78.7^{\mathrm{ab}} \pm 2.43$ & $63.7^{\mathrm{c}} \pm 1.41$ & $74.7^{b} \pm 3.00$ & $76.1^{\mathrm{b}} \pm 4.17$ & $84.5^{\mathrm{ab}} \pm 4.25$ & $82.1^{\mathrm{a}} \pm 1.24$ & $* * *$ \\
\hline Cysteine & $69.4^{\mathrm{ab}} \pm 2.66$ & $51.0^{c} \pm 4.42$ & $60.9^{b c} \pm 4.37$ & $62.8^{\mathrm{bc}} \pm 4.70$ & $77.1^{\mathrm{a}} \pm 3.26$ & $77.2^{\mathrm{a}} \pm 7.44$ & $* * *$ \\
\hline Glycine & $60.0^{\mathrm{cd}} \pm 6.31$ & $56.6^{\mathrm{d}} \pm 1.23$ & $68.3^{\mathrm{bc}} \pm 2.51$ & $77.9^{\mathrm{ab}} \pm 4.01$ & $85.1^{\mathrm{a}} \pm 0.49$ & $87.6^{a} \pm 3.67$ & $* * *$ \\
\hline Glutamic acid & $87.6^{\mathrm{a}} \pm 1.58$ & $71.0^{c} \pm 1.86$ & $81.6^{\mathrm{ab}} \pm 2.43$ & $80.7^{\mathrm{b}} \pm 2.36$ & $80.0^{\mathrm{ab}} \pm 1.42$ & $82.4^{\mathrm{a}} \pm 3.64$ & $* * *$ \\
\hline Serine & $68.3^{\mathrm{bc}} \pm 4.0$ & $62.4^{\mathrm{c}} \pm 4.23$ & $73.0^{\mathrm{b}} \pm 2.18$ & $75.8^{\mathrm{ab}} \pm 5.13$ & $84.6^{\mathrm{a}} \pm 1.95$ & $83.0^{\mathrm{a}} \pm 1.46$ & $* * *$ \\
\hline Average & $77.1^{b} \pm 8.05$ & $60.3^{\mathrm{d}} \pm 7.24$ & $71.7^{c} \pm 7.12$ & $77.6^{\mathrm{b}} \pm 5.14$ & $83.4^{\mathrm{a}} \pm 3.32$ & $85.1^{\mathrm{a}} \pm 3.84$ & $* * *$ \\
\hline
\end{tabular}

${ }^{1}$ Data were average of 3 samples of each feed ingredient; diet based on each sample was fed to six replicates each containing six birds.

a,b,c,d Values sharing different superscripts within rows are statistically significant $(\mathrm{p}<0.05)$.

$* \mathrm{p}<0.05 ; * * \mathrm{p}<0.01 ; * * * \mathrm{p}<0.001$.

$51.0 \%$ to $76.9 \%$, respectively (Table 9). The SBMArgentine and SBM-India had the highest SIAAD among vegetable protein meals. Most of AAs from SBM-Argentine and SBM-India had higher SIAAD than other vegetable protein meals. However, SIAAD of SFM was more $(\mathrm{p}<0.05)$ than CSM. Guar meal had the lowest SIAAD $(\mathrm{p}<0.05)$.

The low SIAAD of SFM (77.1\%) in our study was due to higher fiber content. The fiber fraction was $>24 \%$ in the samples studied and fiber content was negatively correlated with AA digestibility (Senkoylu and Dale, 1999). Bell (1993) reported reduced digestibility due to high hull portion while studying canola meal. The SIAAD of CSM (71.7\%) had almost similar values reported by Rostagno et al. (2005), Sauvant et al. (2004) and Evonik (2010). However, contrasting values were reported by Ravindran et al. (2005). The higher fiber, gossypol contents (Phelps, 1966) and condensed tannins (Yu et al., 1993) were the cause of reduced AA digestibility in CSM (Ravindran et al., 2005). These anti-nutritional substances not only increase digesta viscosity but interact with digestive enzymes making them unavailable and consequently reducing the AA digestibility. The GM's SIAAD (60.3\%) was the lowest among all ingredients in this study. This low digestibility when compared to findings of Nadeem et al. (2005) might be due to different animal used, sample sources (Wang and Parsons, 1998) or chemical composition. Difference in agronomic practices, environmental, soil conditions
(Ravindran et al., 2014) and processing may influence feed ingredient's digestibility. The substances like $\beta$-mannans and gums in GM may form complex with digestive enzymes and increase digesta viscosity and thus reduce AA digestibility. Data regarding AA digestibility in GM were limited in different database systems reported by some workers (Evonik, 2010).

The SIAAD of SBM from Argentine and Indian regions was similar to those reported by other workers (Evonik, 2010; Ravindran et al., 2014). Similarly, SIAAD of SBMArgentine and SBM-India did not differ between them (Evonik, 2010). However, in this trial, numerically higher SIAAD of SBM-Argentine $(85.1 \%)$ than that of SBMIndian $(83.4 \%)$ was supported by the findings of Ravindran et al. (2014). The higher fiber in Indian-SBM might have reduced AA digestibility. The reason of increased SBMArgentine digestibility might be the varying nutrient composition, processing conditions (Ravindran et al., 2014) and temperature of cultivar conditions (Piper and Boote, 1999). Generally, processing enhances AA availability. However, under extreme conditions like high temperature either it may lead to Maillard reactions making AAs unavailable to birds (Ahmad et al., 2007) or damage AAs particularly the basic AAs (Fenwick and Curtis, 1980). Other than applying heat and pressure during processing, even just grinding of ingredient is not without any effect. For example, grinding may change shape and size of 
particle without affecting chemical composition. Enhanced particle's surface area during grinding allows more enzymatic action, enhancing the digestion (Bryden et al., 2009). In present study, the SIAAD of FM was $77.6 \%$ which supported the findings of Evonik (2010) but were lower than those reported by Rostagno et al. (2005) and Sauvant et al. (2004). Possible reason of varying FM's SIAAD might be the difference in fish variety because FM is prepared from a variety of fish and each variety varies in its nutrient composition and AA digestibility.

Arginine from GM, CSM, SMB-Argentine, and SBMIndia had the highest SIAAD. Cysteine from GM, FM, and SBM from both regions while glycine $(60.0 \%)$ from SFM and Lysine (56.8\%) from CSM had the lowest SIAAD. However, SIAAD of methionine from SFM (91.4\%) and alanine from FM (84\%) was high (Table 9). It is well recognized that AAs are heat susceptible during processing especially the SBM (Parsons et al., 1992), canola meal (Newkirk et al., 2003) and SFM (Zhang and Parsons, 1994). The pressurized steam or heat during processing may destroy or alter AA, making them unavailable to animal's requirements (Wang and Parsons, 1998). The lower lysine digestibility from CSM in present study supported the findings of other scientists (Ravindran et al., 2005). Ravindran et al. (2005) documented that the reason of reduced lysine digestibility in CSM might be the formation of indigestible complex between lysine and gossypol during processing. The heat supply in presence of free gossypol accelerated the process of complex formation especially with free AAs (Baliga and Lyman, 1957). The other reason of lysine's reduced digestibility is its free $\alpha$-amino group which is highly susceptible to damage (Ravindran et al., 2005). The reduced lysine availability is not only specific for CSM but was evident in several other oilseed meals (Zhang and Parsons, 1994). Generally, in animal protein meals, cysteine was the lowest digestible (Heartland Lysine, 1996; Evonik, 2010) because it is the most affected AA by high temperature and pressure during processing (Wang and Parsons, 1998). The exact phenomenon by which processing adversely affects the cysteine is not clear (Wang and Parsons, 1998) but might be due to lysinoalanine or lanthionine formation (Robbins et al., 1980).

\section{CONCLUSION}

The corn and RB had same ( $p>0.05)$ SIAAD in cereals. Similarly in cereal byproducts, WB and RP had equal SIAAD value $(p>0.05)$. Among protein meals, the SBMArgentine, SBM-India had higher SIAAD values $(p<0.05)$ than those of SFM, FM, and CSM. However, the GM had the lowest $(p<0.05)$ SIAAD value among protein meals studied. Formulating broiler diets using SIAAD values of various feed ingredients may not only make broiler production a cost effective enterprise but will also reduce the environmental pollution.

\section{CONFLICT OF INTEREST}

We certify that there is no conflict of interest with any financial organization regarding the material discussed in the manuscript.

\section{ACKNOWLEDGMENTS}

This study was supported by Higher Education Commission of Pakistan. The authors are grateful to Sadiq Feeds (Pvt.) Ltd. Rawalpindi, Pakistan, for providing chicks, feeds and laboratory facilities.

\section{REFERENCES}

Adedokun, S. A., C. M. Parsons, M. S. Lilburn, O. Adeola, and T. J. Applegate. 2007. Endogenous amino acid flow in broiler chicks is affected by the age of birds and method of estimation. Poult. Sci. 86:2590-2597.

Adedokun, S. A., O. Adeola, C. M. Parsons, M. S. Lilburn, and T. J. Applegate. 2008. Standardized ileal amino acid digestibility of plant feedstuffs in broiler chickens and turkey poults using a nitrogen-free or casein diet. Poult. Sci. 87:2535-2548.

Ahmad, G., T. Mushtaq, M. A. Mirza, and Z. Ahmad. 2007. Comparative bio-efficacy of lysine from L-lysine hydrochloride or L-lysine sulfate in basal diets containing graded levels of canola meal for female broiler chickens. Poult. Sci. 86:525-530.

AOAC. 2000. Official Methods of Analysis. 17 $7^{\text {th }}$ ed. AOAC Int., Gaithersburg, MD, USA.

Baliga, B. P. and C. M. Lyman. 1957. Preliminary report on the nutritional significance of bound gossypol in cottonseed meal. J. Am. Oil Chem. Soc. 34:21-24.

Bandegan, A., W. Guenter, D. Hoehler, G. H. Crow, and C. M. Nyachoti. 2009. Standardized ileal amino acid digestibility in wheat distillers dried grains with solubles for broilers. Poult. Sci. 88:2592-2599.

Bell, J. M. 1993. Factors affecting the nutritional value of canola meal: A Review. Can. J. Anim. Sci. 73:679-697.

Bryden, W. L., X. Li, G. Ravindran, L. I. Hew, and V. Ravindran. 2009. Ileal Digestible Amino Acid Values in Feedstuffs for Poultry. Rural Industrial Research and Development Corporation. RIRDC Publication no 09/071. Gatton, Australia.

Dari, R. L., A. M. Penz Jr., A. M. Kessler, and H. C. Jost. 2005. Use of digestible amino acids and the concept of ideal protein in feed formulation for broilers. J. Appl. Poult. Res. 14:195203.

Evonik. 2010. AMINODat 4.0. Evonik Industries, Evonik Degussa GmbH, Hanau-Wolfgang, Germany.

Fenwick, G. R. and R. F. Curtis. 1980. Rapeseed meal and its usage in poultry diets: A review. Anim. Feed Sci. Technol. 5:255-298. 
Heartland Lysine. 1996. Digestibility of Essential Amino Acids for Poultry and Swine, version 3.3. Heartland Lysine, Inc., Chicago, IL, USA.

Huang, K. H., V. Ravindran, X. Li, and W. L. Bryden. 2005. Influence of age on the apparent ileal amino acid digestibility of feed ingredient for broiler chickens. Br. Poult. Sci. 46:236245.

Kim, E. J. and A. Corzo. 2012. Interactive effect of age, sex, and strain on apparent ileal amino acid digestibility of soybean meal and an animal by-product blend in broilers. Poult. Sci. 91:908-917.

Kim, E. J., P. L. Utterback, and C. M. Parsons. 2012a. Comparison of amino acid digestibility coefficients for soybean meal, canola meal, fish meal and meat and bone meal among 3 different bioassays. Poult. Sci. 91:1350-1355.

Kim, E. J., P. L. Utterback, and C. M. Parsons. 2012b. Comparison of amino acid digestibility coefficients for corn, corn gluten meal and corn distillers dried grains with solubles among 3 different bioassays. Poult. Sci. 91:3141-3147.

Kong, C. and O. Adeola. 2014. Invited review: Evaluation of amino acid and energy utilization in feedstuff for swine and poultry diets. Asian Australas. J. Anim. Sci. 27:917-925.

Lemme, A., V. Ravindran, and W. L. Bryden. 2004. Ileal digestibility of amino acid in feed ingredients for broilers World's Poult. Sci. J. 60:423-437.

Moter, V. and H. H. Stein. 2004. Effect of feed intake on endogenous losses and amino acid and energy digestibility by growing pigs. J. Anim. Sci. 82:3518-3525.

Moughan, P. J., G. Schuttert, and M. Leenaars. 1992. Endogenous amino acid flow in the stomach and small intestine of the young growing rat. J. Sci. Food Agric. 60:437-442.

Nadeem, M. A., A. H. Gillani, A. G. Khan, and M. Nisa. 2005 True metabolizable energy values of poultry feedstuffs in Pakistan. Int. J. Agric. Biol. 6:990-994.

Newkirk, R. W., H. L. Classen, and M. J. Edney. 2003. Effects of prepress-solvent extraction on the nutritional value of canola meal for broiler chickens. Anim. Feed Sci. Technol. 104:111119.

NRC. 1994. Nutrient Requirements of Poultry. 9th edn. National Academy Press, Washington DC, USA.

Palliyeguru, M. W. C. D., S. P. Rose, and A. M. Mackenzie. 2010 Effect of dietary protein concentration on the incidence of subclinical necrotic enteritis and growth performance of broiler chicken. Poult. Sci. 89:34-43.

Parsons, C. M., K. Hashimoto, K. J. Wedekind, Y. Han, and D. H. Baker. 1992. Effect of over processing on availability of amino acids and energy in soybean meal. Poult. Sci. 71:133-140.

Phelps, R. A. 1966. Cottonseed meal for poultry: from research to practical application. World's Poult. Sci. J. 22:86-112.
Piper, E. L. and K. J. Boote. 1999. Temperature and cultivar effects on soybean seed oil and protein concentrations. J. Am. Oil Chem. Soc. 76:1233-1241.

Ravindran, V., L. I. Hew, and W. L. Bryden. 2005. Apparent ileal digestibility of amino acids in dietary ingredients for broiler chickens. J. Anim. Sci. 81:85-97.

Ravindran, V., L. I. Hew, G. Ravindran, and W. L. Bryden. 1999. A comparison of ileal digesta and excreta analysis for the determination of amino acid digestibility in food ingredients for poultry. Br. Poult. Sci. 40:266-274.

Ravindran, V., M. R. Abdollahi, and S. M. Bootwalla. 2014. Nutrient analysis, metabolizable energy and digestible amino acids of soybean meals of different regions for broilers. Poult. Sci. 93:2567-2577.

Robbins, K. R., D. H. Baker, and J. W. Finley. 1980. Studies on the utilization of lysinoalanine and lanthionine. J. Nutr. 110:907915

Rostagno, H. S., L. F. T. Albino, J. L. Donzele, P. C. Gomes, R. F. Oliveira, D. C. Lopes, A. S. Ferreira, and S. L. T. Barreto. 2005. Brazilian Tables for Poultry and Swine: Composition of Feedstuffs and Nutritional Requirements, 2 ed. Universidade Federal de Viçosa, Viçosa, Brazil.

SAS (Statistical Analysis System), 2009: User's Guide: Statistics, SAS Institute, Inc., Cary, NC, USA.

Sauvant, D., J. M. Perez, and G. Tran. 2004. Tables of composition and nutritive value of feed materials: Pigs, poultry, cattle, sheep, goats, rabbits, horses, fish (Eds. D. Sauvant, J. M. Perez, and G. Tran). Paris, France.

Senkoylu, N. and N. Dale. 1999. Sunflower meal in poultry diets: a review. World's Poult. Sci. J. 55:153-174.

Sibbald, I. R. 1987. Estimation of bioavailable amino acids in feeding stuffs for poultry and pigs: A review with emphasis on balance experiments. Can. J. Anim. Sci. 67:291-300.

Stein, H. H., B. Seve, M. F. Fuller, P. J. Moughan, and C. F. M. de Lange. 2007. Invited review: Amino acid bioavailability and digestibility in pig feed ingredients: Terminology and application. J. Anim. Sci. 85:172-180.

Wang, X. and C. M. Parsons. 1998. Effect of raw material source, processing system, and processing temperatures on amino acid digestibility of meat and bone meals. Poult. Sci. 77:834-841.

Warren, B. E. and D. J. Farrell. 1991. The nutritive value of fullfat and defatted Australian rice bran. V. The apparent retention of minerals and apparent digestibility of amino acids in chicken and adult cockerels fitted with cannulae. Anim. Feed Sci. Technol. 27:232-242.

Yu, F., T. N. Barry, P. J. Moughan, and G. F. Wilson. 1993. Condensed tannin and gossypol concentrations in cotton seeds and in processed cottonseed meal. J. Sci. Food Agric. 63:7-15.

Zhang, Y. and C. M. Parsons. 1994. Effects of over processing on the nutritional quality of sunflower meal. Poult. Sci. 73:436442 